\title{
Risk Stratification and Factors Associated with Abandonment of Tuberculosis Treatment in a Secondary Referral Unit
}

This article was published in the following Dove Press journal: Patient Preference and Adherence

\section{Wanessa da Silva Peres Bezerra (D) \\ Everton Ferreira Lemos (iD) Thiago Nascimento do Prado ${ }^{3}$ Larissa Taemy Kayano $\mathbb{D}^{2}$ Stefany Zacarin de Souza ${ }^{2}$ Cláudia Elizabeth Volpe Chaves (D) ${ }^{1,4}$ \\ Anamaria Mello Miranda Paniago (D) 1,2,4 \\ Albert Schiaveto de Souza $\mathbb{1 D}^{5,6}$ Sandra Maria do Valle Leone de Oliveira ${ }^{2,4,6}$}

\footnotetext{
'Postgraduate Program in Infectious and Parasitic Diseases, Federal University of Mato Grosso do Sul, Campo Grande, Mato Grosso do Sul, Brazil; ${ }^{2}$ School of Medicine, Federal University of Mato Grosso do Sul, Campo Grande, Mato Grosso do Sul, Brazil; ${ }^{3}$ Nursing Department, Federal University of Espírito Santo, Vitória, Espírito Santo, Brazil; ${ }^{4}$ Maria Aparecida Pedrossian University Hospital, EBSERH, Campo Grande, Mato Grosso do Sul, Brazil; ${ }^{5}$ Biosciences Institute, Federal University of Mato Grosso do Sul, Campo Grande, Mato Grosso do Sul, Brazil;

${ }^{6}$ Postgraduate Program in Family Health, Biosciences Institute, Federal University of Mato Grosso do Sul, Campo Grande, Mato Grosso do Sul, Brazil
}

Correspondence: Sandra Maria do Valle Leone de Oliveira

School of Medicine, Federal University of Mato Grosso do Sul, Cidade Universitária, Caixa Postal 549, Unidade 9, Campo Grande CEP 79070-900 Mato Grosso do Sul, Brazil

Tel +55 6733457370

Email sandra.leone@ufms.br
Purpose: To study the factors associated with the risk of discontinuing active tuberculosis treatment among patients in an outpatient referral unit and to analyze the association between patients' abandonment risk score and their odds of discontinuing the treatment.

Patients and Methods: In this cohort study, tuberculosis patients were prospectively followed up from June 2012 through July 2019 at a secondary tuberculosis referral unit in Mato Grosso do Sul, Brazil. At initial consultation, patients were interviewed using a standardized questionnaire and were assigned a score for the risk of treatment abandonment by the nurse. Univariate and multivariate analyses were performed using logistic regression. Results: One hundred and forty-eight patients were included in the study, of which $65.0 \%$ $(96 / 148)$ were male. Their mean age was $43.3 \pm 14.8$ years (range: $18-89$ years). Smoking, drug use, repeated admissions, and a high abandonment risk score were the variables associated with the highest risk of discontinuing the treatment. The rate of tuberculosis and human immunodeficiency virus coinfection was $37.2 \%$. The overall rate of global treatment abandonment was $10.8 \%$ (95\% confidence interval [CI]: 6.1-16.2). Upon stratification of patients that abandoned by the risk score, $22.9 \%(8 / 35)$ of the ones that abandoned had a high risk, $10.9 \%(6 / 55)$ had an intermediate risk, and 3.5\% (2/58) had a low risk of treatment abandonment. In multivariate analysis, the factors associated with abandoning the treatment were smoking [adjusted odds ratio $(\mathrm{aOR})=4.91(95 \% \mathrm{CI}: 1.08,22.32)$ ] and undergoing retreatment $(\mathrm{aOR})=3.66$ (95\% CI: 1.04, 12 88) .

Conclusion: Smoking and undergoing retreatment were independent risk factors for tuberculosis treatment abandonment in this center. Risk stratification can help prioritize the strengthening of treatment adherence among patients at higher risk of abandoning treatment in referral units.

Keywords: tuberculosis, patient acceptance of health care, patient withdrawal, classification

\section{Introduction}

Tuberculosis is the fourth leading cause of death from infectious diseases overall and the first among infectious diseases in people living with human immunodeficiency virus (HIV) (PLHIV) worldwide. ${ }^{1}$ Essential efforts taken to control this disease include prevention, early diagnosis, and adequate treatment. ${ }^{2}$ Low treatment adherence and treatment abandonment can result in the maintenance of the disease transmission chain, increased mortality, and development of mycobacterial resistance. ${ }^{2,3}$

The World Health Organization defines an abandonment rate of up to $5 \%$ as "acceptable". 4 The dropout rate in Brazil in 2017 was 10.8\% among new pulmonary cases confirmed through laboratory testing and varied from $1.5 \%$ in Acre to 
$14.3 \%$ in Goiás. In the state of Mato Grosso do Sul, this rate was $9.3 \%$. In the same Brazilian population, the states Amapá and Piauí had dropout rates lower than or equal to $5 \%$. In the same year, a high percentage of cases with no recorded outcome was observed, which hindered a better estimate of the abandonment rate. ${ }^{5}$

Factors influencing treatment abandonment can occur at various levels, such as at the individual level and at the level of the service that performs treatment monitoring. Among the individual-level factors, male gender, unemployment, use of illicit drugs, smoking, alcoholism, HIV, irregular treatment, and prior treatment. ${ }^{6-8}$

Adherence to tuberculosis treatment is a complex process involving social determinants, biological factors, and factors related to health service organizations. ${ }^{9}$ One of the strategies used to improve adherence to treatment and the correct use of medicines is directly observed therapy (DOT). DOT improves adherence by creating a health professional-patient bond and having health professionals observe the patients taking tuberculosis medication. ${ }^{10}$ The Ministry of Health recommends its employment for all people undergoing treatment for tuberculosis. ${ }^{11}$

However, the success of a health policy is closely related to its implementation, and only $36.9 \%$ of new cases of pulmonary tuberculosis in Brazil underwent DOT in 2017. ${ }^{5}$ Health services in Brazil are organized through health-care networks that arrange for the provision of health actions and services that have integrated technical, logistical, and management support systems and seek to provide comprehensive care. The tuberculosis care service is integrated with primary care, secondary and tertiary referral units, and the hospital network. ${ }^{5}$

Primary care units serve all patients with tuberculosis who use a basic treatment regimen and report only minor adverse effects. These units are also responsible for the patient's DOT (Directly Observed Treatment) and health professional-patient bond, when referred to a secondary or tertiary referral unit. A secondary referral unit for tuberculosis is meant to serve patients referred for clarification of their case status, who use special treatment regimens, report major adverse effects, and have comorbidities that are difficult to manage. ${ }^{5}$ Primary health care in Brazil does not cover $100 \%$ of the population in the municipalities, ${ }^{10}$ and several studies have shown that the effectiveness of DOT depends on the context and factors related to the health service. $^{12,13}$

The cure rate among new laboratory-confirmed cases in Brazil was $71 \%$ in 2017 and ranged from $46.6 \%$ to
92.5\% across Brazilian states. This rate is lower among socially disadvantaged patients and those co-infected with HIV. ${ }^{12,13}$ These observations reiterate the need for improvements in disease control using individualized care.

Accurate diagnosis of the risk of patient abandonment is challenging for health-care professionals involved in tuberculosis programs at every level. ${ }^{14}$ A decision-making tool that helps to prioritize care in a reference outpatient clinic by using risk stratification and customizing treatment plans to cater individual needs of patients can increase treatment effectiveness and outpatient monitoring, thereby reducing the workload of health-care professionals. $^{14}$

This study aimed to determine factors associated with the risk of treatment abandonment, ie, discontinuing active tuberculosis treatment among patients receiving care at a secondary referral unit in Mato Grosso do Sul and to analyze the association of patients' abandonment risk score with treatment outcome.

\section{Patients and Methods}

This observational, analytical, quantitative cohort study involving patient follow-up was carried out in the secondary reference clinic for tuberculosis at the Hospital Dia Professora Esterina Corsini of the Federal University of Mato Grosso do Sul, in the Midwest region of Brazil. All individuals with a clinical-epidemiological and/or laboratory diagnosis of active tuberculosis and were admitted to the hospital between July 2012 and June 2019 were invited to participate in the study. Patients invited to participate in the study were asked to sign an informed consent form. The research was approved by the Human Research Ethics Committee of the Federal University of Mato Grosso do Sul (approval number 3.355.036). This study was conducted in accordance with the Declaration of Helsinki.

Patients aged 18 years and above who had started treatment for tuberculosis and been followed up for at least 30 consecutive days in our service were included in the study. Patients were excluded if they died, or if their tuberculosis diagnosis had changed, if they were incarcerated or transferred, or if they did not complete treatment by June 2019.

Epidemiological and clinical data were prospectively collected using a standardized form. A risk score for treatment abandonment was calculated for all patients by the nurse at the initial consultation using a questionnaire elaborated from regression and neural network (Figure 1). ${ }^{14}$ The score was calculated for the following 


\begin{tabular}{|l|l|l|}
\hline \multicolumn{4}{|l|}{ Abandonment Risk Score Questionnaire } & 30 years or older (0) \\
\hline Age & Less than 30 years (10) & Female (0) \\
\hline Sex & Male (5) & 1 minimum wage or more (0) \\
\hline Average income & Less than 1 minimum wage (10) & No (10) \\
\hline Occupation & Yes (0) & No (20) \\
\hline Religion & Yes (0) & No (0) \\
\hline Illicit drugs & Yes (25) & No (0) \\
\hline Smoke & Yes (10) & No (0) \\
\hline Previous treatment for TB & Yes (10) &
\end{tabular}

Figure I Abandonment risk score questionnaire.Notes: Source: Adapted from Prado TN. Utilização de redes neurais e regressão logística para a predição de fatores de abandono do tratamento da tuberculose nos municípios prioritários para o controle no Estado do Espírito Santo [dissertação] [Adapted from Prado TN. Use of neural networks and logistic regression to predict factors for the abandonment of tuberculosis treatment in priority municipalities for control in the State of Espírito Santo [dissertation]]. Vitória: Universidade Federal do Espírito Santo; 2010. Portuguese. ${ }^{14}$

variables: sex, age, cigarette smoking habits, drug use, occupation, religion, and whether treatment for tuberculosis has been previously started. A score between 0 and 10 was assigned for each variable, yielding a total summed score of up to 100 points, which was categorized into low ( $<20$ points), intermediate $(20-40$ points $)$ and high $(\geq 45$ points) risk of discontinuing the treatment. ${ }^{14}$

Patients were followed up until treatment completion or abandonment. The primary outcome analyzed was abandonment of treatment or no abandonment. Treatment abandonment was considered to have occurred when the patient did not come to the health facility for 30 days after the scheduled return date. ${ }^{10}$ Smokers were defined as those who reported smoking every day, and those who had stopped smoking within less than one year before the study. Alcohol users were defined as those who reported regular alcohol consumption and those who stopped drinking less than a year before the study. Tuberculosis was classified as pulmonary, extrapulmonary, and mixed (pulmonary and extrapulmonary). Retreatment referred to patients who were restarting treatment after previous treatment failure, relapse, or abandonment.

The potential study population consisted of 218 patients, and a representative sample of this population was estimated to be 140 patients, considering a margin of error of $5 \%$, a confidence level of $95 \%$, and a response distribution of $50 \%{ }^{15}$ Statistical analyses were performed using the Statistical Package for the Social Sciences software (SPSS), version 23.0. Missing data were excluded from the analyses.
Categorical variables were reported as frequencies and percentages, and the associations between them were analyzed using the chi-square test with Bonferroni correction when necessary, that is, when the variable was categorical, with a significance level of $\mathrm{p}<0.05$. Odds ratios (OR) and their $95 \%$ confidence intervals $(95 \% \mathrm{CI})$ were used to assess the association of variables with treatment abandonment. Multivariate analysis was conducted by adjusting for potential confounders, identified as variables having a $p$-value of $\leq 0.20$ in the univariate analysis. The level of statistical significance used for the multivariate analysis was 0.05 .

\section{Results}

A total of 205 patients were initially enrolled in the study. Fifty-seven patients $(27.5 \%)$ were excluded from the analyses, and a total of 148 cases were analyzed (Figure 2). The study sample consisted of $65.0 \%$ men, with a mean age of $43.3 \pm$ 14.76 years (range: $18-89$ years). In terms of education, $48.8 \%$ $(61 / 125)$ of the patients had completed elementary school, and $12 \%(15 / 125)$ had completed higher education. Illicit drug use was reported by $18.2 \%(27 / 148)$ of the patients.

The dropout rate in this study was $10.8 \%$ (95\% CI: 6.1 , 16.2). Smoking $(p=0.012)$ and drug use $(p=0.035)$ were associated with abandonment. The characteristics gender, age, color, education, occupation, alcoholism, previous incarceration, place of residence, and income were not associated with treatment abandonment. Demographic characteristics of patients according to the treatment outcome are shown in Table 1. 


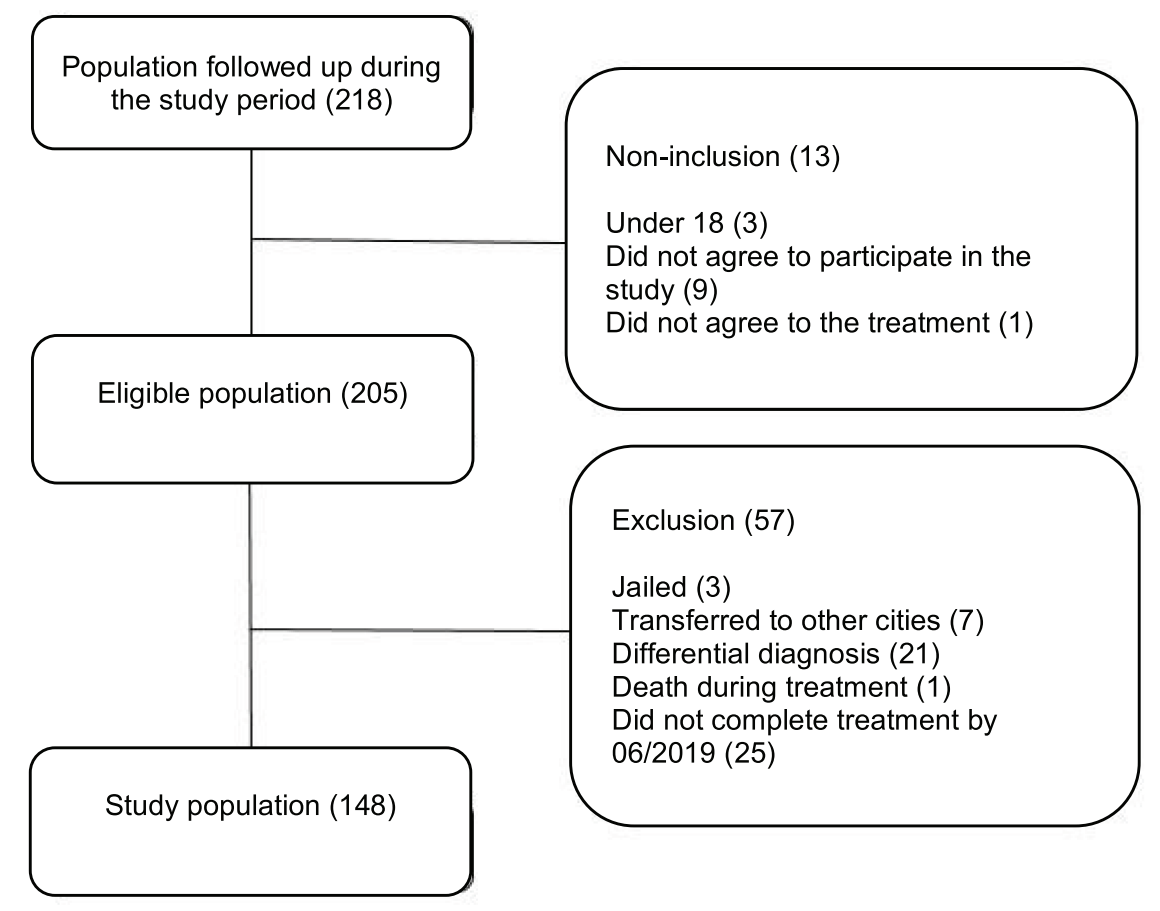

Figure 2 Flowchart of study participant selection.

Of the total study participants, $37.2 \%$ (55/148) were HIV positive, of which $74.5 \%$ (41/55) were men, 49.1\% (27/55) had pulmonary tuberculosis, $34.5 \%(19 / 55)$ had extrapulmonary tuberculosis, and 16.4\% (9/55) had mixed tuberculosis. Isolated pulmonary tuberculosis represented 56.8\% (84/148) of the cases. The most common forms of extrapulmonary tuberculosis were ganglionic, $11.5 \%$ (17/148); pleural, 11.5\% (17/148); and meningeal, 3.4\% (5/148), with a total of 19 different forms of tuberculosis. The diagnosis of tuberculosis was confirmed through laboratory testing in $58.1 \%(86 / 148)$ of patients. Among HIV patients, the laboratory confirmation rate was $49.1 \%(27 / 55)$.

Twenty-three of the 148 patients were undergoing retreatment for tuberculosis, of which $69.6 \%(16 / 23)$ were doing so due to abandonment or relapse, and $26.1 \%$ (4/16) of those patients abandoned the treatment again. Based on risk stratification using the questionnaire, the distribution of abandonment risk scores assessing risk of dropout was as follows: $39.2 \%$ (58/148), 37.2\% (55/148), and $23.6 \%(35 / 148)$ of the patients had low, intermediate, and high abandonment risk scores, respectively. Of the sixteen patients who abandoned treatment, $87.5 \%(14 / 16)$ were at high or intermediate risk of abandonment, and $12.5 \%(2 / 16)$ were at low risk. The dropout rate among patients with low, intermediate, and high risk was 3.5\% (2/ $58), 10.9 \%(6 / 55)$, and $22.9 \%(8 / 35)$, respectively. The retreatment $(\mathrm{p}=0.010)$ and type of tuberculosis $(\mathrm{p}=$ 0.026) were related to abandonment. The variables HIV, type of diagnosis, and adverse reactions were not associated with treatment abandonment. Characteristics of patients' and clinical variables according to the treatment outcome are shown in Table 2.

In multivariate analysis, smoking and retreatment for tuberculosis had significant associations with treatment abandonment. After adjusting for potential confounders, smokers had higher odds of abandonment $(\mathrm{aOR}=4.91$; 95\% CI: $1.08,22.32 ; \mathrm{p}=0.040)$ than non-smokers. Patients who were undergoing retreatment had higher odds of abandonment compared with those who were not $(\mathrm{aOR}=3.66 ; 95 \% \mathrm{CI}: 1.04,12.88)$ (Table 3$)$.

Variables that had a p-value of less than 0.20 in the univariate analysis were included in the multivariate analysis; they are highlighted in bold in Tables 1-3 shows only those variables that were significant in the multivariate analysis. Patients with a high abandonment risk score had greater odds of discontinuing the treatment compared with those with a low score $(\mathrm{OR}=8.30 ; 95 \% \mathrm{CI}$ : 1.65 , 41.76; $\mathrm{p}=0.003)($ Table 4).

\section{Discussion}

This study shows that several factors including smoking, retreatment of the disease, and high abandonment risk 
Table I Characteristics of Patients Followed Up at a Secondary Reference Clinic for Tuberculosis in Campo Grande, MS, Between 2012 and 2019, According to Treatment Abandonment $(n=148)$

\begin{tabular}{|c|c|c|c|c|}
\hline \multirow[t]{2}{*}{ Variables } & \multirow[b]{2}{*}{$\begin{array}{l}\text { Total \% (n) } \\
\%(n)\end{array}$} & \multicolumn{2}{|c|}{ Abandonment } & \multirow[b]{2}{*}{$p$-value } \\
\hline & & $\begin{array}{l}\text { Yes } \\
\%(n)\end{array}$ & $\begin{array}{l}\text { No } \\
\%(n)\end{array}$ & \\
\hline $\begin{array}{l}\text { Sex } \\
\text { Male } \\
\text { Female }\end{array}$ & $\begin{array}{l}64.9(96) \\
35.1(52)\end{array}$ & $\begin{array}{l}13.5(13) \\
5.8(3)\end{array}$ & $\begin{array}{l}86.5(83) \\
94.2(49)\end{array}$ & 0.146 \\
\hline $\begin{array}{l}\text { Average age (years) } \\
18-42 \\
43-89\end{array}$ & $\begin{array}{l}46.6(69) \\
53.4(79)\end{array}$ & $\begin{array}{l}8.7(6) \\
12.7(10)\end{array}$ & $\begin{array}{l}91.3(63) \\
87.3(69)\end{array}$ & 0.439 \\
\hline $\begin{array}{l}\text { Race } \\
\text { White } \\
\text { Non-white }\end{array}$ & $\begin{array}{l}31.3(46) \\
68.2(101)\end{array}$ & $\begin{array}{l}4.3(2) \\
12.9(13)\end{array}$ & $\begin{array}{l}95.7(44) \\
87.1(88)\end{array}$ & 0.113 \\
\hline $\begin{array}{l}\text { Educational level } \\
\text { Primary } \\
\text { Secondary } \\
\text { University degree }\end{array}$ & $\begin{array}{l}48.8(61) \\
39.2(49) \\
12.0(15)\end{array}$ & $\begin{array}{l}6.6(4) \\
8.2(4) \\
13.3(2)\end{array}$ & $\begin{array}{l}93.4(57) \\
91.8(45) \\
86.7(13)\end{array}$ & 0.686 \\
\hline $\begin{array}{l}\text { Occupation } \\
\text { No } \\
\text { Yes }\end{array}$ & $\begin{array}{l}55.4(82) \\
37.2(55)\end{array}$ & $\begin{array}{l}\text { I3.4 (I I) } \\
5.5(3)\end{array}$ & $\begin{array}{l}86.6(7 I) \\
94.5(52)\end{array}$ & 0.132 \\
\hline $\begin{array}{l}\text { Smoking } \\
\text { No } \\
\text { Yes }\end{array}$ & $\begin{array}{l}65.5(97) \\
34.1 \text { (5I) }\end{array}$ & $\begin{array}{l}6.2(6) \\
19.6(10)\end{array}$ & $\begin{array}{l}93.8(9 I) \\
80.4(4 I)\end{array}$ & 0.012 \\
\hline $\begin{array}{l}\text { Alcohol abuse } \\
\text { No } \\
\text { Yes }\end{array}$ & $\begin{array}{l}65.5(97) \\
34.1(51)\end{array}$ & $\begin{array}{l}7.2(7) \\
17.6(9)\end{array}$ & $\begin{array}{l}92.8(90) \\
82.4(42)\end{array}$ & 0.052 \\
\hline $\begin{array}{l}\text { Illicit drugs } \\
\text { No } \\
\text { Yes }\end{array}$ & $\begin{array}{l}81.8(121) \\
18.2(27)\end{array}$ & $\begin{array}{l}8.3(10) \\
22.2(6)\end{array}$ & $\begin{array}{l}91.7(\mathrm{III}) \\
77.8(2 \mathrm{I})\end{array}$ & 0.035 \\
\hline $\begin{array}{l}\text { Had been in prison } \\
\text { No } \\
\text { Yes }\end{array}$ & $\begin{array}{l}31.8(47) \\
12.2(18)\end{array}$ & $\begin{array}{l}8.5(4) \\
I I . I(2)\end{array}$ & $\begin{array}{l}91.5(43) \\
88.9(16)\end{array}$ & 0.746 \\
\hline $\begin{array}{l}\text { Residence } \\
\text { Capital city } \\
\text { Other cities }\end{array}$ & $\begin{array}{l}82.4(122) \\
17.6(26)\end{array}$ & $\begin{array}{l}11.5(14) \\
7.7(2)\end{array}$ & $\begin{array}{l}88.5(108) \\
92.3(24)\end{array}$ & 0.573 \\
\hline $\begin{array}{l}\text { Income } \\
\text { I average salary or more } \\
\text { Less than I average salary }\end{array}$ & $\begin{array}{l}50.0(74) \\
48.6(72)\end{array}$ & $\begin{array}{l}8.1(6) \\
13.9(10)\end{array}$ & $\begin{array}{l}91.9(68) \\
86.1(62)\end{array}$ & 0.264 \\
\hline
\end{tabular}

Notes: Results are presented as percentages in each group (abandoned and not abandoned). The data in parentheses are presented as absolute frequency. Values in bold indicate variables with $\mathrm{p}<0.20$ in univariate analysis that were included in the multivariate analysis.

score were associated with the abandonment of tuberculosis treatment by patients. The profile of patients receiving care in the secondary tuberculosis referral unit in this study matched the characteristics of tuberculosis patients reported in the literature. ${ }^{16-20}$
Although the dropout rate in this study was high compared with the WHO target of 5\%, it is important to highlight that the study setting was a secondary reference clinic for tuberculosis. Other studies on tuberculosis patients in referral units also report high abandonment rates varying 
Table 2 Clinical Variables According to Abandonment of Patients Followed Up at the Secondary Reference Clinic for Tuberculosis, 2012 to 2019, Campo Grande/MS ( $=148)$

\begin{tabular}{|c|c|c|c|c|}
\hline \multirow[t]{3}{*}{ Variables } & \multirow[b]{2}{*}{ Total } & \multicolumn{2}{|c|}{ Abandonment } & \multirow{3}{*}{ p-value } \\
\hline & & Yes & No & \\
\hline & $\%(n)$ & $\%(n)$ & $\%(n)$ & \\
\hline \multicolumn{5}{|l|}{ HIV } \\
\hline Negative & $62.6(93)$ & $12.9(12)$ & $87.1(81)$ & 0.286 \\
\hline Positive & $37.4(55)$ & $7.3(4)$ & $92.7(5 \mathrm{I})$ & \\
\hline \multicolumn{5}{|l|}{ Type of diagnosis } \\
\hline Laboratory tests & $58.1(86)$ & $12.8(1 \mathrm{I})$ & $87.2(75)$ & $0.36 \mathrm{I}$ \\
\hline Clinical/epidemiology & $41.9(62)$ & $8.1(5)$ & $91.9(57)$ & \\
\hline \multicolumn{5}{|l|}{ Type of entry } \\
\hline Retreatment & $15.9(23)$ & $26.1(6)$ & $73.9(17)$ & 0.010 \\
\hline New case & $84.1(125)$ & $8.0(10)$ & $92.0(115)$ & \\
\hline \multicolumn{5}{|l|}{ Adverse effects } \\
\hline Major & II.2 (I7) & I I.8 (2) & $88.2(15)$ & 0.643 \\
\hline Minor & $81.8(12 I)$ & $10.5(10)$ & 91.7 (III) & \\
\hline \multicolumn{5}{|l|}{ Type of tuberculosis } \\
\hline Pulmonary/extrapulmonary & $12.8(35)$ & $26.3(5)^{\mathrm{a}}$ & $73.7(14)$ & \\
\hline Pulmonary & $56.8(84)$ & $11.9(10)^{\mathrm{ab}}$ & $88.1(74)$ & 0.026 \\
\hline Extrapulmonary & $30.4(45)$ & $2.2(1)^{b}$ & $97.8(44)$ & \\
\hline
\end{tabular}

Notes: Data are presented as percentages in each group (abandoned and not abandoned). The data in parentheses are presented as absolute frequencies. Values in bold indicate variables with $p<0.20$ in the univariate analysis that were included in the multivariate analysis. ${ }^{a}, b$, ab ${ }^{2}$ ifferent letters in the column indicate a significant difference between the variations of the variable, in relation to the percentage of dropout (chi-square test with Bonferroni correction, $\mathrm{p}<0.05$ ).

Abbreviation: HIV, human immunodeficiency virus.

from $14.6 \%$ to $24.0 \%{ }^{16,17,19,21,22}$ A study comparing the different levels of care in Brazilian capitals showed that process and outcome indicators were better among patients who remained in primary care throughout the treatment period, and patients who were treated in secondary and tertiary care units had an abandonment rate of $22.7 \%$, compared with only $16.8 \%$ in primary care. ${ }^{23}$

A secondary referral unit for tuberculosis should ideally serve patients referred for clarification of case status, who follow special treatment regimens, report major adverse effects, and have comorbidities, where performing DOT together with primary care is recommended. However, the reality is that due to the low coverage of primary care in many Brazilian states, this strategy cannot be fully implemented. ${ }^{24}$ Low adherence to the treatment for chronic comorbidities prevails in conditions of illiteracy, poverty, and unemployment. ${ }^{11,25}$ However, in our study, there was no association between level of education, income, and unemployment.

Table 3 Factors Associated with Treatment Abandonment Among Study Participants, Campo Grande, MS (n= I48)

\begin{tabular}{|c|c|c|c|c|c|}
\hline \multirow[t]{2}{*}{ Variables } & \multicolumn{2}{|c|}{ Abandonment } & \multirow[b]{2}{*}{ Odds Ratio (95\% Cl) } & \multirow[b]{2}{*}{ aOR $(95 \% \mathrm{Cl})$} & \multirow[b]{2}{*}{$\begin{array}{l}\text { Adjusted } \\
\text { p- value }\end{array}$} \\
\hline & Yes \% (n) & No \% (n) & & & \\
\hline \multicolumn{6}{|l|}{ Smoker } \\
\hline Yes & $80.4(4 I)$ & $19.6(10)$ & $3.70(1.12-13.14)$ & $4.91(1.08-22.32)$ & 0.040 \\
\hline No & $93.8(91)$ & $6.2(6)$ & I & I & \\
\hline \multicolumn{6}{|l|}{ Type of entry } \\
\hline Retreatment & $73.9(17)$ & $26.1(6)$ & $4.06(1.06-14.14)$ & $3.66(1.04-12.88)$ & 0.048 \\
\hline New case & $92.0(115)$ & $8.0(10)$ & I & 1 & \\
\hline
\end{tabular}

Notes: Results are presented as percentages in each group (abandoned and not abandoned). The data in parentheses are presented as absolute frequencies. Abbreviation: aOR, adjusted odds ratio. 
Table 4 Distribution of Patients According to Abandonment Risk Score and Actual Treatment Abandonment $(n=148)$

\begin{tabular}{|l|l|l|l|l|l|}
\hline \multirow{2}{*}{ Score } & \multicolumn{3}{|l|}{ Abandonment } & & \multirow{2}{*}{ Adjusted p-value } \\
\cline { 2 - 5 } & Total \% (n) & Yes \% (n) & No \% (n) & Odds Ratio (95\% Cl) & \\
\hline Low & $39.2(58)$ & $3.5(2)^{\mathrm{b}}$ & $96.6(56)$ & 1 & - \\
Medium & $37.2(55)$ & $10.9(6)^{\mathrm{ab}}$ & $89.1(49)$ & $3.43(0.67-17.77)$ & 0.122 \\
High & $23.6(35)$ & $22.9(8)^{\mathrm{a}}$ & $77.1(27)$ & $8.30(1.65-41.76)$ & 0.003 \\
\hline
\end{tabular}

Notes: Results are presented as percentages in each group (abandoned and not abandoned). The data in parentheses are presented as absolute frequencies. ${ }^{\text {a, b }}$ Different letters in the column indicate a significant difference between the variations of the variable, in relation to the percentage of dropout (chi-square test with Bonferroni correction, $\mathrm{p}<0.05$ )

Patients who smoked were more likely to quit treatment than non-smokers, since smoking was independently associated with the study outcome. A study carried out in Rio de Janeiro also showed a strong association between smoking and discontinuing treatment $(\mathrm{RR}=6.29) .{ }^{26}$ Some studies have found that smoking is often not a factor predicting treatment abandonment; however, it is important to note that the population of smokers consists mostly of older people, among whom treatment abandonment is less frequent. Therefore, the effect of this variable may be confounded. ${ }^{7}$

In this study, it was not possible to assess lack of laboratory confirmation of the diagnosis $(41.9 \%)$ as a risk factor for abandonment. In the literature, patients without laboratory confirmation of the diagnosis have a high risk of abandonment, ${ }^{27}$ which can be explained by the fact that the service is a secondary referral unit that receives patients whose diagnoses are difficult to elucidate, including those co-infected with HIV. The rate of tuberculosis/HIV co-infection in $37.2 \%$ of the patients was similar to that found in the literature (13.9$35.5 \%$ ). Although HIV serological status did not significantly influence dropout in our study, some studies have identified this variable as a protective factor. ${ }^{20,22}$ One possible explanation is the organization of services and the care network structured to treat people with HIV within the last 20 years. However, some studies also emphasize co-infection as a risk factor for abandonment. ${ }^{28}$

The odds of treatment abandonment among patients undergoing retreatment was 3.66 times higher than those not undergoing retreatment, with $26.1 \%(6 / 23)$ of retreatment patients having given up treatment. One study identified that $76.4 \%$ of patients undergoing retreatment ended up abandoning their treatment. ${ }^{29}$ Similarly, another study found a significant association between treatment abandonment and patients undergoing retreatment. ${ }^{30}$

A study of patients with paracoccidioidomycosis and tuberculosis suggested that respiratory symptoms cause greater limitations in daily life, leading patients to be more concerned about their treatment. ${ }^{22}$ However, patients are concerned about the disease while feeling sick, and when they feel clinical improvement during the maintenance phase of the treatment, they generally believe they are cured, which is not the case in extrapulmonary tuberculosis. $^{31,32}$ However, improvement in respiratory symptoms after a period of treatment is a factor influencing abandonment. Despite existing guidelines, the low perception of disease severity coupled with all the difficulties of treatment can lead the patient to abandon therapy. $^{33}$

Upon examination of the association of the treatment outcome with risk strata defined by the abandonment risk score, a significant difference was found between patients with high scores and those with low scores. A low risk of treatment abandonment was observed in $36.2 \%$ of patients, where the dropout rate was only $3.5 \%$. Those at high risk accounted for $23.7 \%$ of all patients, and $22.9 \%$ effectively abandoned treatment. An internal validation study of the abandonment risk score found that a high probability score result increased the probability of needing supervised treatment by a factor of $23 .^{14}$

To achieve universal coverage as recommended, DOT can certainly be performed for patients with a low probability of abandonment. However, this would lead to an increased investment of health-care professionals' time and effort in a population that may not receive direct benefits, as well as decreasing the time invested in patients at high risk of abandonment. Thus, advocating the same strategy for all patients may lead to missed opportunities to prioritize increased quality monitoring among a population at greater risk of abandonment.

This study had some limitations. It was necessary to retrospectively search for incomplete data; the study sample was limited to the operational routine of the service studied. The total number of participants may not have allowed for the detection of stronger associations. However, the present study is unique in that it evaluates the factors associated with treatment abandonment in a 
secondary referral unit in the state and also assesses the relationship between the abandonment score and the outcome in a different population from the one used for development of the score.

\section{Conclusion}

The factors associated with increased risk of abandoning treatment at the secondary referral clinic were smoking and tuberculosis retreatment. Both smoking and retreatment of the disease are variables that make up the abandonment risk score used in this study. These factors can therefore be considered as priorities while developing strategies to improve adherence. Risk stratification using an abandonment risk score tool in the monitoring and treatment of patients with tuberculosis is useful in quantifying the risk of abandoning treatment at a secondary referral unit. Considering that the strategy for providing family health coverage is variable in Brazil, the use of this tool in other levels of health services should be explored to prioritize efforts toward patients most likely to drop out. In addition, we conclude that the abandonment risk score can assist health-care professionals; and despite being one more form to fill, it is simple, fast, and helps to prioritize patients who require more attention, thereby reducing the workload.

\section{Acknowledgments}

This study was financed in part by the Universidade Federal de Mato Grosso do Sul, and in part by the Coordenação de Aperfeiçoamento de Pessoal de Nível Superior - Brasil (CAPES) - Finance Code 001.

\section{Disclosure}

The authors report no conflicts of interest in this work.

\section{References}

1. World Health Organization [homepage on the Internet]. Global tuberculosis report; 2019. Available from: https://www.who.int/tb/publica tions/global_report/en/. Accessed January 11, 2020.

2. Barreira D. Os desafios para a eliminação da tuberculose no Brasil. Epidemiol Serv Saúde. 2018;27(1):e00100009. doi:10.5123/S167949742018000100009

3. Okethwangu D, Birungi D, Biribawa C, et al. Multidrug-resistant tuberculosis outbreak associated with poor treatment adherence and delayed treatment: Arua District, Uganda, 2013-2017. BMC Infect Dis. 2019;19(1):387. doi:10.1186/s12879-019-4014-3

4. Ministério da Saúde (BR). Secretaria De Vigilância Em Saúde, Departamento De Vigilância Epidemiológica. Guia De Vigilância Epidemiológica. $6^{\mathrm{a}}$ ed. Brasília (DF): MS; 2005.

5. Ministério da Saúde (BR). Secretaria De Vigilância Em Saúde. Brasil Livre Da Tuberculose: Evolução Dos Cenários Epidemiológicos e Operacionais Da Doença. Boletim Epidemiológico. Brasília: Ministério da Saúde; 2019.
6. Albuquerque MF, Leitão CC, Campelo AR, de Souza WV, Salustiano A. Fatores prognósticos para o desfecho do tratamento da tuberculose pulmonar em Recife, Pernambuco, Brasil. Rev Panam Salud Publica. 2001;9(6):368-374. doi:10.1590/S1020-49892001000600003

7. Harling G, Neto ASL, Sousa GS, Machado MMT, Castro MC. Determinants of tuberculosis transmission and treatment abandonment in Fortaleza, Brazil. BMC Public Health. 2017;17(1):508. doi:10.1186/s12889-017-4435-0

8. Venkatesh U, Srivastava DK, Srivastava AK, Tiwari HC. Epidemiological profile of multidrug-resistant tuberculosis patients in Gorakhpur Division, Uttar Pradesh, India. J Family Med Prim Care. 2018;7(3):589-595. doi:10.4103/jfmpc.jfmpc_99_17

9. Munro SA, Lewin SA, Smith HJ, Engel ME, Fretheim A, Volmink J. Patient adherence to tuberculosis treatment: a systematic review of qualitative research. PLoS Med. 2007;4(7):e238. doi:10.1371/journal. pmed.0040238

10. e-Gestor AB [homepage on the Internet]. Ministério da Saúde. Secretaria de Atenção Primária à Saúde (SAPS). Informação e gestão da atençao básica; 2017. Available from: https://egestorab. s a ude.gov.br/paginas/acessoPubico/relatorios/ relHistoricoCoberturaAB.xhtml. Accessed January 14, 2020.

11. Ministério da Saúde (BR). Manual De Recomendações Para o Controle Da Tuberculose No Brasil. Brasília; 2019.

12. Radilla-Chávez P, Laniado-Laborín R. Results of directly observed treatment for tuberculosis in Ensenada, Mexico: not all DOTS programs are created equally. Int J Tuberc Lung Dis. 2007;11(3):289-292.

13. Ministério da Saúde (BR). Tratamento Diretamente Observado (TDO) Da Tuberculose Na Atenção Básica: Protocolo De Enfermagem. Secretaria De Vigilância Em Saúde, Departamento De Vigilância Epidemiológica. Brasília: Ministério da Saúde; 2011.

14. Prado TN. Utilização De Redes Neurais e Regressão Logística Para a Predição De Fatores De Abandono Do Tratamento Da Tuberculose Nos Municípios Prioritários Para o Controle No Estado Do Espírito Santo [Dissertação]. Vitória: Universidade Federal do Espírito Santo; 2010.

15. RAOSOFT CALCULATOR [homepage on the Internet]. Sample size calculator. Available from: http://www.raosoft.com/samplesize.html. Accessed February 7, 2020.

16. Costa RR, Silva MR, Rocha AS, et al. Tuberculose: perfil epidemiológico em hospital referência no tratamento da doença. Rev Med Minas Gerais. 2014;(Supl 5):57-64.

17. Almeida AA, Barros HJM, Silva TC, et al. Perfil clínico epidemiológico de casos de tuberculose. Rev Enferm UFPE Online. 2015;9:1007-1017.

18. Zhu Y, Wu J, Feng X, et al. Patient characteristics and perceived health status of individuals with HIV and tuberculosis coinfection in Guangxi, China. Medicine (Baltimore). 2017;96(14):e6475. doi:10.1097/MD.0000000000006475

19. Bastos SH, Taminato M, Fernandes H, Figuereido TMRM, Nichiata LYI, Hymn P. Perfil sociodemográfico e de saúde da coinfecção tuberculose/HIV no Brasil: revisão sistemática. Rev Bras Enferm. 2019;72(5):1389-1396. doi:10.1590/0034-7167-2018-0285

20. Viveiros F, Mota M, Brinca P, Carvahlo A, Duarte R. Adesão ao rastreio e tratamento da tuberculose em doentes infetados com o vírus da imunodeficiência humana. Rev Port Pneumol. 2013;19(3):134138. doi:10.1016/j.rppneu.2013.03.001

21. Andrade UV, Oliveira SMVL, Chang MR, et al. Adesão ao tratamento de pacientes com paracoccidioidomicose na Região CentroOeste do Brasil. J Bras Pneumol. 2019;45(2).

22. Silva CCAV, Andrade MS, Cardoso MD. Fatores associados ao abandono do tratamento de tuberculose em indivíduos acompanhados em unidades de saúde de referência na cidade do Recife, Estado de Pernambuco, Brasil, entre 2005 e 2010. Epidemiol e Serviços Saúde. 2013;22(1):77-85. doi:10.5123/S1679-4974201 3000100008 
23. Bartholomay P, Pelissari DM, Navegantes WA, Yadon ZE, Heldal E. Qualidade da assistência à tuberculose em diferentes níveis de atenção à saúde no Brasil em 2013. Rev Panam Salud Publica. 2016;39(1):3-11.

24. Ministério da Saúde (BR). Secretaria de Vigilância em Saúde. Indicadores prioritários para o monitoramento do plano nacional pelo fim da tuberculose como problema de saúde pública no Brasil. BolEpidemiol. 2017;48(8):1-11.

25. World Health Organization. Innovative Care for Chronic Conditions: Building Blocks for Action: Global Report. Geneva: World Health Organization; 2002.

26. Cailleaux-Cezar M, Loredo C, Silva JRL, Conde MB. Impacto do tabagismo na conversão de cultura e no desfecho do tratamento da tuberculose pulmonar no Brasil: estudo de coorte retrospectivo. $J$ Bras Pneumol. 2018;44(2):99-105.

27. Natal S, Valente J, Gerhardt G, Penna ML. Modelo de predição para o abandono do tratamento da tuberculose pulmonar. Bol Pneumol Sanitária. 1999;7(1):65-78.
28. Ferreira MRL, Bonfim RO, Siqueira TC, Orfão N. Abandono do tratamento da tuberculose: uma revisão integrativa. Rev Enferm Contemp. 2018;7(1):63-71.

29. Oliveira HB, Moreira Filho DC. Abandono de tratamento e recidiva da tuberculose: aspectos de episódios prévios, Campinas, SP, Brasil, 1993-1994. Rev Saúde Pública. 2000;34(5):437-443.

30. Ferreira SMB, Silva AMC, Botelho C. Abandono do tratamento da tuberculose pulmonar em Cuiabá - MT - Brasil. J Bras Pneumol. 2005;31(5):427-435. doi:10.1590/S1806-37132005000500011

31. Mendes AM, Fensterseifer LM. Tuberculose: porque os pacientes abandonam o tratamento? Bol Pneumol Sanitária. 2004;12(1):27-38.

32. Yoon HJ, Song YG, Park WI, Choi JP, Chang KH. Clinical manifestations and diagnosis of extrapulmonary tuberculosis. Yonsei Med J. 2004;45(3):453-461.

33. Driver CR, Matus SP, Bayuga S, Winters AI, Munsiff SS. Factors associated with tuberculosis treatment interruption in New York City. J Public Health Manag Pract. 2005;11(4):361-368. doi:10.1097/ 00124784-200507000-00017
Patient Preference and Adherence

\section{Publish your work in this journal}

Patient Preference and Adherence is an international, peer-reviewed, open access journal that focusing on the growing importance of patient preference and adherence throughout the therapeutic continuum. Patient satisfaction, acceptability, quality of life, compliance, persistence and their role in developing new therapeutic modalities and compounds to optimize clinical outcomes for existing disease

\section{Dovepress}

states are major areas of interest for the journal. This journal has been accepted for indexing on PubMed Central. The manuscript management system is completely online and includes a very quick and fair peer-review system, which is all easy to use. Visit http:// www.dovepress.com/testimonials.php to read real quotes from published authors. 